\title{
THE EFFECT OF SMARTPHONE USAGE FREQUENCY ON ONLINE REPERTOIRE BY IMMIGRANT DIGITAL GROUPS
}

\author{
Mashita Putri Hatama ${ }^{1}$, Reza Safitri ${ }^{2}$, and Anang Sujoko ${ }^{3}$ \\ Postgraduate Communication Science, Faculty of Social and Political Sciences, Brawijaya University ${ }^{123}$ \\ Email: ichihatama04@gmail.com
}

Diterima : 30-11-2020

Disetujui : 06-01-2021

Diterbitkan : 17-02-2021

\begin{abstract}
ABSTRAK
Terinspirasi dari gagasan Repertoar Media di berbagai penelitian, artikel ini menganalisis mengenai apa yang kelompok Digital Imigran bangun dalam menggunakan Smartphone dalam kehidupan sehari-hari. Repertoar merupakan pemilihan media yang dipakai secara berkala berdasarkan kegunaannya dan menjadi rutinitas yang dapat diidentifikasi. Penelitian ini mengelompokkan aktifitas di Smartphone untuk berbagai kepentingan menjadi 5 tema diantaranya ; Hiburan, Transaksi, Konsumsi, Produksi / Partisipasi, dan Layanan Kesejahteraan Sosial. Bagaimana hasil dari repertoar online di Smartphone berdasarkan 5 tema tersebut.. Apakah Frequency penggunaan dengan menggunakan teori Uses and Gratification dapat membentuk Repertoar dari 5 tema yang dikelompokkan. Artikel ini mengambil data di Universitas Muhammadiyah Malang untuk dosen dan karyawan aktif yang merupakan kelompok Digital Imigran dengan menyebarkan kuesioner online dan teknik pengambilan sampel menggunakan rumus Slovin (N: 107). Untuk dapat mengidentifikasi repertoar online di Smartphone menggunakan analisis PLS (Partial Least Square) sehingga dapat diketahui nilai koefisien pada variabel $X$ dalam mempengaruhi variabel Y. Hasil menunjukkan bahwa, tema konsumsi mempunyai nilai koefisien 0,849 > dari t-Table 0,6 yang bermakna memiliki kontribusi terbesar dibanding 4 dimensi lainnya sehingga konsumsi merupakan repertoar online di Smartphone pada kelompok Digital Imigran dan Frequency penggunaan (teori Uses \& Gratification) memiliki pengaruh yang dominan dalam pembentukan repertoar online di Smartphone dengan nilai statistik 4,526 > dari t-Table 1,96. Kesimpulannya bahwa durasi dan Frequency menggunakan Smartphone dapat menjadikan masyarakat Indonesia khususnya kelompok digital imigran menjadi konsumen yang aktif untuk berbelanja online di e-commerce.
\end{abstract}

Kata Kunci : Repertoar ${ }^{1}$;Smartphone ${ }^{2}$; Digital Imigran ${ }^{3}$; Uses and Gratification ${ }^{4}$

\begin{abstract}
Inspired by the Media Repertoire idea in various studies, this article analyzes what digital immigrant groups build-in using Smartphones in everyday life. The repertoire is the selection of media used periodically based on its usefulness and became an identifiable routine. This study grouped Smartphones activities for various interests into 5 themes including; Entertainment, Transactions, Consumption, Production/Participation, and Social Welfare Services. How the results of the online repertoire on Smartphones based on these 5 themes. Whether the frequency of use using The Uses and Gratification theory can form a Repertoire of 5 grouped themes, the researcher take this data at the University of Muhammadiyah Malang for lecturers and active employees who are a group of Digital Immigrants by distributing online questionnaires and sampling techniques using the formula Slovin (N: 107). To identify
\end{abstract}


the online repertoire in Smartphones using PLS (Partial Least Square) analysis so that it can be known as the coefficient value in variable $X$ in influencing variable $Y$. The results showed that consumption theme has a coefficient value of $0.849>$ from $t$-table 0.6 which means it has the largest contribution compared to other 4 dimensions so that consumption is an online repertoire in Smartphones in the Digital Immigrant group and the frequency of use (Uses \& Gratification theory) has a dominant influence in the formation of online repertoire in Smartphones with a statistical value of 4,526 > from t-table 1.96. The conclusion is that the duration and frequency of using smartphones can make Indonesian people, especially digital groups of immigrants, become active consumers to shop online in e-commerce.

Keywords : Repertoire ${ }^{1}$; Smartphone ${ }^{2}$; Digital Immigrants $^{3}$; Uses and Gratification ${ }^{4}$

\section{INTRODUCTION}

The development of technology offers several media that can be chosen by the audience, including television, radio, magazines, newspapers, newspapers, even smartphones. Audiences can choose their own way to get information. Baran and Davis (2011) argue that people use specific media or media content to get specific information according to their needs. This reflects that human beings are active audiences in choosing the desired media channel. However, a large number of media choices will have some effect on the public to choose what media suits their needs.

One way to overcome diverse media is by using repertoire methods (Heeter, 1985). The repertoire is selecting media used periodically based on their usefulness or communication channels used periodically and become identifiable routines (Heeter, 1985). The small subset of channels is a mechanism to overcome the increasingly abundant and complex media environment (Heeter, 1985). From a subset of channels that people choose to access information, those sub-channels can be identified. The media repertoire is strongly tied to everyday human life (Taneja et al., 2012). People overcame a large number of media choices by grouping various media on relatively smaller channels and according to their wishes

Research on the repertoire began with television's emergence as a viral communication channel in the 90s (Ferguson \& Perse, 1993); (Yuan \& Webster, 2006). Repertoire research is also growing by adding new media, such as radio, newspapers, laptops/computers and television (Taneja et al., 2012) in the United States, (Kim, 2016) in South Korea. Besides, research on the repertoire is also seen from the selectivity of what media it uses and can be known from the preferences of the most in-demand and the limitations of cost (media that can be consumed or accessed (Kim, 2016). Not only that, demographic factors and psychological factors can also influence some differences from each person's media repertoire (Hasebrink \& Domeyer, 2012) ; (Taneja et al., 2012). Age factors can also influence the concept of each person's media repertoire method, from young people to the elderly also have differences in conceptualizing their own media repertoire (Edgerly et al., 2018). In fact, older people have their own media repertoire concept and experience new challenges in fighting for technological life after dealing with traditional media (Olsson et al., 2019b), (Givskov \& Deuze, 2018). 
The fact that smartphones are one of the new media in industry 4.0 is indeed a change of revolution in Indonesia. However, its presence applies to native digital groups born from the digital dimension and the digital group of immigrants. Rapid information is currently growing alongside the digital world, so it does not close the possibility that senior citizens / elderly also try to face new media called smartphones. Statistical studies have found that older people actually have access in ICT and that they also make use of smartphones, computers, tablets and so on online to meet their needs (Olsson et al., 2019a).

Smartphone use is the key to reorientation that follows technological developments and reaches into new routines that will gradually be defined as a new life (Ytre-Arne, 2019). The part that is not left behind is also the service provided in smartphones that are applications connected to the Internet. Applications that every week try to become human social needs to send each other texts with pictures or videos via WhatsApp, we can post our activities to be known by the whole public with Instagram, even health services.

Indonesia ranks as the fifth-largest Internet user country in the world (Azzura, 2019). According to Internet World Stats, Internet usage in Indonesia ranks among the four countries in Asia with the most users (Masitha et al., 2019). APJII survey 2017 has been conducted in several regions in Indonesia with 2500 respondents aged over 13 years; average smartphone usage is connected with an internet connection with a variety of duration of use, ranging from 1-3 hours which is about $43.89 \%$, 4-7 hours around $29.63 \%$, and more than 7 hours about $26.48 \%$ (Loen, 2018). This is why it is necessary to know the use of online repertoire carried out by the community in the young, elderly/late adult, what are the benefits of smartphones for young seniors. In theoretical considerations, the media repertoire method can be proven conceptually using the Uses and Gratification (U\&G) approach. The Uses \& Gratification approach is the most prominent explanation for selective media selection (Hasebrink \& Popp, 2006). This theoretical aspect of Uses and Gratification becomes a dependent variable.

The concept used to look at repertoire studies by previous research uses many Uses \& Gratification theory. The concept is the most prominent in selective media exposure. With Uses $\&$ Gratification theory, the media repertoire concept is identifiable to media user groups based on specific combinations of motives related to such media (Hasebrink \& Domeyer, 2012). Using the Uses \& Gratification theory, researchers can see the media's exposure that the individual uses by looking at the uses in terms of the resulting exposure to show what elements the individual is using in accessing the technology. Jung, Kim, and Chan (2014) researched the Smartphone repertoire in South Korea with uses \& gratification theory useful to see the frequency with which a person uses a Smartphone. O'Keefe, Ward, and Shepard (2002) also used uses \& gratification theory to find environmental communication in search of information about agriculture by urban and suburban people. 
The concept of online repertoire in Smartphones that researchers want to review is based on research by Olsson, Samuelsson, and Viscovi (Olsson et al., 2019b) which examined the study of online repertoire on Internet-connected media devices with 5 dimensions that include different themes, including (1) Entertainment (2) Transactions (3) Consumption (4) Production / Participation (5) Social Welfare Services. These dimensions can determine the direction of media use by media users. They can see the repertoire built by the audience. (1) Entertainment Dimension refers to entertainment that involves online activities such as chatting, watching, listening, reading on a Smartphone. (2) Transaction Dimension of practices relating to household needs, electricity and water payment, ticket purchase or hotel booking or paying credit dependents on Smartphone. (3) Consumption dimension related to household, such as consumption, meets household needs, namely buying goods through e-commerce and using services such as Gojek, Grab, and Uber on Smartphones. (4) Production Dimensions / Participation of various modes of expression that are focused on genres and topics. This dimension relates to expressions such as taking pictures, editing, writing articles, commenting on opinions, sending files on Smartphones. (5) The Dimension of Social Welfare Services relates to social services for health, taxes, and insurance on Smartphones.

In addition to looking at the concept of online repertoire in Smartphones, researchers wanted to see the frequency generated from the online repertoire that audiences have built on Smartphones based on the Uses \& Gratification theory. By knowing the frequency of smartphone use, researchers can find out the influence of frequency on the online repertoire in smartphones built by the audience. What is produced in the continuous use of Smartphones so that it can be identified and become the rhythm of daily life.

The researcher's view this time wanted to take the perspective of a digital group of immigrants aged 40-60 years in Malang. Researchers want to see what digital groups of immigrants do when it comes to adapting to new media. Smartphones are a medium used in looking at the concept of online repertoire that digital groups of immigrants built. This study looks at a more specific and detailed repertoire when the number of various media options. This is useful for analyzing online practices, especially Smartphones in digital groups of immigrants experiencing a changing media environment (traditional to contemporary). Besides, this approach is very useful because the online world offers a wide variety of options where people will navigate.

\section{RESEARCH METHODS}

This research uses a quantitative approach that emphasizes objective phenomena and examines specific populations and samples. Data collection using research instrument that is quantitative/numerical statistics processed and tested with statistical data to test hypotheses. This research belongs to the category of correlational (explanative) associative research. It tests the influence between two variables, namely variables $\mathrm{X}$ and $\mathrm{Y}$, that give rise to causality or 
causality processes. Correlational associative research involves collecting data to determine if there is an influence between variable $X$, namely the frequency of smartphone use to the variable $\mathrm{Y}$, namely the online repertoire in Smartphones.

The research location was conducted at the University of Muhammadiyah Malang, namely lecturers and employees. The population taken is 1200 people. In this case, the sample must meet the criteria of a group aged 40-60 years, both lecturers and employees at the University of Muhammadiyah Malang. Sampling using the Slovin method because the number of samples for the population is less than 10,000 . Sampling method, according to Slovin, is as follows:

Description :

$$
\mathrm{n}=\frac{N}{N \cdot d^{2}+1}
$$

$\mathrm{n}=$ Number of samples

$\mathrm{N}=$ Number of population

$\mathrm{d}=$ Precision/Desired deviation rate

Thus, the population of 1200 is calculated with a deviation rate of $10 \%(0.1)$, then the resulting formula is as follows:

$$
\begin{gathered}
\mathrm{n}=\frac{N}{N \cdot d^{2}+1} \\
\mathrm{n}=\frac{1200}{1200 \cdot 0 \cdot 1^{2}+1} \\
\mathrm{n}=\frac{1200}{(1200) \cdot(0.01)+1} \\
\mathrm{n}=\frac{1200}{13}=92.3 \text { rounded to } 93
\end{gathered}
$$

Thus, the sample that should be taken by researchers is 93 respondents. However, researchers took 107 samples in the study on lecturers and employees at the University of Muhammadiyah Malang.

The data collection instrument used is using questionnaires. Questionnaires were given in the form of questions about demographic data: gender, age, and occupation, then questions about activities carried out in using smartphones by 5 dimensions including (1) entertainment, (2) transactions, (3) consumption, (4) production/participation, and (5) social welfare services. Besides, the next question is about the old frequency of smartphone usage per day including (1) < 1 hour per day, (2) 2-3 hours per day, (3) 4-5 hours per day, (4) 6-7 hours per day, (5) > 7 hours per day. Before distributing research instruments to population samples, researchers have conducted research instrument tests using reliability tests using Alpha Cronbach (Nurgiyantoro, 2018) and validity tests using Pearson Product Moment (Arikunto, 2002). The way to see the extent of validity in the research instrument is to look at the value of Significance (Sig). The condition that the value of significance < of 0.05 and if value $>0.05$ then declared invalid. Meanwhile, to look at a reliable research instrument or not is if the Value of Cronbanch Alpha is 
greater than 0.60. In this case, the research instrument is declared valid and reliable (consistent) to continue the research.

Data analysis that will be used in this research is using PLS (Partial Least Square), a multivariate statistical technique that can be used to handle many response variables and explanatory variables. This analysis is a great alternative to multiple regression analysis and regression of the main components since this method is more robust or immune. Robust means that the model's parameters do not change much when new samples are taken from the total population (Geladi \& Kowalski, 1986). Partial Least Square is a predictive technique that can handle many independent or exogenous variables, even if it is multicollinear between these variables (Ramzan et al., 2010).

The use of Partial Least Square can know the value of the dimensions in the variable $\mathrm{Y}$ is not only the value of a variable, so that when known the value of each dimension in the variable $\mathrm{Y}$ then, namely 5 dimensions including entertainment, transactions, consumption, production/participation, and social health services. The value is used to see the online activities carried out by respondents on Smartphones where more value contributes to the variable. It will be clearly known as the repertoire of online audiences on Smartphones. The next stage of the largest known value in variable Y's dimension analyzed the influence between the variable frequency $(\mathrm{X})$ to the variable online repertoire in Smartphones $(\mathrm{Y})$.

\section{RESULTS AND DISCUSSIONS}

From the results of the dissemination of questionnaires, respondents obtained as many as 107 samples, namely lecturers and employees of the University of Muhammadiyah Malang are as follows:

\section{Table 1. Respondent's Identity By Occupation}

\begin{tabular}{lcc}
\hline Occupation & Frequency & Percentage \\
\hline Lecturer & 80 & $75 \%$ \\
\hline Employees & 27 & $25 \%$ \\
\hline Total & $\mathbf{1 0 7}$ & $\mathbf{1 0 0 \%}$ \\
\hline
\end{tabular}

Source: Processed Researcher 2020

The selection of jobs between employees and lecturers is adjusted to APJII (2018) that lecturers who fall into the teacher category have a high penetration in using the Internet of 100 while private employees also have a high penetration rate of 85.7. Work is essential for 
connections to others using the Internet; therefore, work affects people's interests in different sectors (Ytre-Arne, 2019).

In addition to being based on work, respondents' age is also a measure to know the online repertoire on Smartphones. The respondents studied were 40-60 years old who are digital immigrants.

Table 2 Respondents' Identities By Age

\begin{tabular}{lcc}
\hline Age & Frequency & Percentage \\
\hline $40-45$ year & 13 & $12 \%$ \\
\hline $46-51$ year & 19 & $18 \%$ \\
\hline $52-57$ year & 63 & $59 \%$ \\
\hline $58-62$ year & 10 & $9 \%$ \\
\hline No Answering & 2 & $2 \%$ \\
\hline Total & $\mathbf{1 0 7}$ & $\mathbf{1 0 0 \%}$ \\
\hline
\end{tabular}

Source: Processed Researcher 2020

The age selection is also based on research that the selected Digital Immigrant group must be based on the age still able to use the technology, because a previous survey in Switzerland said Internet users are more inclined to the age of $<70$ years, at the age of $>70$ years has been reluctant to use new technology due to physical dexterity (Friemel, 2016). The age grouping is also based on respondents who have long used gadgets as a communication medium because in Autry \& Berge research (2011) explained that individuals who have been exposed to technology regularly would most likely be easier to program the brain to input technology differently even if born not from digitization.

Gender differences were also seen to determine the number of men and women in the study. Here are the data of men and women who answered the research questionnaire:

Table 3 Respondent's Identity By Gender

\begin{tabular}{lcc}
\hline Gender & Frequency & Percentage \\
\hline Men & 62 & $58 \%$ \\
\hline Women & 45 & $42 \%$ \\
\hline Total & $\mathbf{1 0 7}$ & $\mathbf{1 0 0 \%}$ \\
\hline
\end{tabular}

Source: Processed Researcher 2020

Gender differences can also affect the use of technology; men use technology more than women (Olsson et al., 2019b). Research in South Korea also mentioned that men are more likely than men (62.8\% and 38.2\% of women who use Smartphones (Jung et al., 2014). The percentage of respondents was also more men, namely $58 \%$ and women $42 \%$. Friemel (Friemel, 2016) also suggested a gender gap between men and women that men use online media more often. Gender 
differences are also factors influencing digital use and have a high and strong correlation (Friemel, 2016).

The results of the descriptive analysis of variable X, namely, Frequency of Smartphone use from research respondents are as follows:

Table 4 Descriptive Analysis of Frequency of Use

\begin{tabular}{lcc}
\hline Frequency of Use & Frequency & Percentage \\
\hline$<1$ hour/day & 7 & $7 \%$ \\
\hline $2-3$ hour/day & 32 & $30 \%$ \\
\hline $4-5$ hour/day & 30 & $28 \%$ \\
\hline $6-7$ hour/day & 18 & $17 \%$ \\
\hline$>7$ hour/day & 20 & $19 \%$ \\
\hline Total & $\mathbf{1 0 7}$ & $\mathbf{1 0 0 \%}$ \\
\hline
\end{tabular}

Source: Processed Researcher 2020

Based on Table 4 known from 107 lecturers and employees at the University of Muhammadiyah Malang, most smartphone users are 2-3 hours per day as many as 32 respondents. This is a habit that is always done by the age of 40-60 years in smartphone use.

Smartphones are a communication media that was present in 2013 and trends in Indonesia in 2016. APJII (2020) researched that Indonesian people have been using Smartphones connected to the Internet for 5 years (from 2013) with a penetration of 9.7. However, most have only been connected for about 7 months to 1 year (2019) with a penetration of 28 . That means that smartphone usage is widely used by the end of 2019, and the average respondent has made Smartphones as a tool that makes it easier for someone to communicate, find information.

In the next Table, we display a descriptive analysis on the online repertoire on Smartphones. There are 5 dimensions formed based on 5 themes on activities carried out online in smartphones: entertainment dimensions, transaction dimensions, consumption dimensions, production/participation dimensions, and social welfare service dimensions. Table 5 is the result of a descriptive analysis of entertainment dimensions:

Table 5 Descriptive Analysis of online repertoire by Entertainment Dimension

\begin{tabular}{|c|c|c|c|c|c|c|c|}
\hline No & Statements & $\mathrm{TP}$ & $\mathrm{J}$ & $\mathrm{C}$ & $\mathrm{S}$ & SS & Mean \\
\hline 1. & Watch Youtube/Netflix/Iflix/Viu & 8 & 53 & 33 & 10 & 3 & 2.50 \\
\hline 2. & Chat on WhatsApp & 1 & 4 & 23 & 55 & 24 & 3.91 \\
\hline 3. & Listen to Music & 25 & 63 & 14 & 5 & 0 & 1.99 \\
\hline
\end{tabular}




\begin{tabular}{|c|c|c|c|c|c|c|c|}
\hline & Read News Online & 3 & & & 20 & 0 & 202 \\
\hline 5. & $\begin{array}{l}\text { Play social media on } \\
\text { Instagram/Facebook/Twitter }\end{array}$ & 24 & 44 & 22 & 15 & 2 & 2.32 \\
\hline
\end{tabular}

\section{Description : TP : Tidak Pernah, J : Jarang, C: Cukup, S : Sering, SS : Sangat Sering}

Source: Processed Researcher 2020

The answer in Table 5 is that the Group of Digital Immigrants love entertainment on Smartphones is the first to Chat on Whatsapp with the highest average of 3.91, which means OFTEN. The second most preferred entertainment is to read online news by 3.03, which means ENOUGH. The third entertainment is to watch Youtube/Netflix/Iflix/VIU by 2.50, meaning SELDOM. Next is Social media on Instagram / Facebook / Twitter of 2.32 has the meaning of RARE, while the last entertainment enjoyed by Digital Immigrants using Smartphones is listening to music as much as 1.99 has the meaning of RARE.

Table 6 is a descriptive analysis of transaction dimensions based on answers from 107 respondents who are lecturers and employees at the University of Muhammadiyah Malang aged 40-60 years are as follows:

Table 6 Descriptive Analysis of online repertoire by Transaction Dimension

\begin{tabular}{|c|c|c|c|c|c|c|c|}
\hline No & Statements & TP & $\mathrm{J}$ & $\mathrm{C}$ & $\mathrm{S}$ & SS & Mean \\
\hline 1. & $\begin{array}{l}\text { Transacting in Mobile banking /Internet } \\
\text { Banking (BNI, BCA, MANDIRI, BANK } \\
\text { JATIM, et al) using Smartphone }\end{array}$ & 42 & 12 & 23 & 24 & 6 & 2.44 \\
\hline 2. & $\begin{array}{l}\text { Transacting with digital wallets (DANA, } \\
\text { OVO,JENIUS,GOPAY) using Smartphone }\end{array}$ & 47 & 36 & 12 & 8 & 4 & 1.93 \\
\hline 3. & $\begin{array}{l}\text { Pay for food or beverages with a digital wallet } \\
\text { (OVO,GOPAY,DANA,more) } \\
\text { using a Smartphone }\end{array}$ & 50 & 36 & 9 & 6 & 6 & 1.90 \\
\hline 4. & $\begin{array}{l}\text { Buy airline tickets/ trains/hotels/buses/ or } \\
\text { Other accommodation with } \\
\text { (Ticket.com,Traveloka,Mister Aladdin, } \\
\text { PegiPegi,AGODA, Reddorz, OYO/more) } \\
\text { Smartphone. }\end{array}$ & 35 & 24 & 24 & 21 & 3 & 2.37 \\
\hline
\end{tabular}




\section{Pay your shopping bill with credit using an \\ $\begin{array}{llllllll}\text { 5. } & \text { app (Kredivo) or other app using a } & 76 & 12 & 13 & 4 & 2 & 1.54\end{array}$ \\ Smartphone.}

\section{Description : TP : Tidak Pernah, J : Jarang, C: Cukup, S : Sering, SS : Sangat Sering}

Source: Processed Researcher 2020

The result of the answer in Table 6 is that the Group of Digital Immigrants, transacting on Smartphones is the first to be in Mobile banking / Internet banking with the highest average of 2.44 which has the meaning of Rare. The second most used transaction is to buy a flight/train/hotel/bus ticket of 2.37 which means Rare. The third transaction is for transactions through digital wallet (DANA, GOPAY, JENIUS, OVO) of 1.93, which means Rare. Furthermore, Transactions use digital wallets to pay for food/beverages of 1.90 which means RARE, while the last transaction used by respondents was to pay for groceries using a credit card of only 1.54 which means NEVER.

Table 7 is a descriptive analysis of the consumption dimension based on answers from 107 respondents who are lecturers and employees at the University of Muhammadiyah Malang aged 40-60 years are as follows:

Table 7 Descriptive Analysis of Online Repertoire by Consumption Dimension

\begin{tabular}{llllllll}
\hline No. & \multicolumn{1}{c}{ Statements } & TP & J & C & S & SS & Mean \\
\hline 1. & $\begin{array}{l}\text { Buy items through the app (Shopee, } \\
\text { Bukalapak, Tokopedia, Zalora, et al) using } \\
\text { a Smartphone. }\end{array}$ & 36 & 38 & 18 & 13 & 2 & 2.13 \\
\hline 2. & $\begin{array}{l}\text { Using delivery to various places, deliver } \\
\text { goods and food/beverages with the } \\
\text { application (Gojek/ GRAB/UBER) with } \\
\text { Smartphone. }\end{array}$ & 32 & 39 & 17 & 14 & 5 & 2.26 \\
\hline $\begin{array}{l}\text { For example, using for service services go } \\
\text { clean, go massage, go med, go pulse with } \\
\quad \text { Smartphone. }\end{array}$ & 77 & 22 & 6 & 2 & 0 & 1.37 \\
\hline 4. & $\begin{array}{l}\text { Buy cinema tickets on TIX.id or other apps } \\
\text { using a Smartphone. }\end{array}$ & 92 & 15 & 0 & 0 & 0 & 1.14 \\
\hline 5. & $\begin{array}{l}\text { Buy books on Amazon or other online } \\
\text { book apps with Smartphone. }\end{array}$ & 77 & 21 & 8 & 1 & 0 & 1.37 \\
\hline
\end{tabular}

Ket : TP : Tidak Pernah, J : Jarang, C: Cukup, S : Sering, SS : Sangat Sering

Source: Processed Researcher 2020 
The result of the answer in Table 7 is that the Group of Digital Immigrants is interested in consuming in the first Smartphone to be sent to various places/goods/food/beverages with the highest average of 2.26 which has the meaning rarely. The second most used consumption is to buy goods through e-commerce on Smartphones of 2.13, which means RARE. The third consumption is for service (go clean, go massage, go med, go pulse) of 1.37, which means never. Next is Consumption to buy books on Amazon.com or other online book application of 1.37 which NEVER means, while the last consumption used by respondents is to buy cinema tickets online only by 1.14 , which means NEVER.

Table 8 is a descriptive analysis of the dimensions of production/participation based on answers from 107 respondents who are lecturers and employees at the University of Muhammadiyah Malang aged 40-60 years are as follows:

Table 8 Descriptive Analysis of online repertoire by Production/ Participation Dimension

\begin{tabular}{|c|c|c|c|c|c|c|c|}
\hline No. & Statements & $\mathrm{TP}$ & $\mathrm{J}$ & $\mathrm{C}$ & S & SS & Mean \\
\hline 1. & $\begin{array}{l}\text { Using Smartphone for } \\
\text { photos/videos/selfies on } \\
\text { Smartphone }\end{array}$ & 2 & 46 & 31 & 22 & 6 & 2.85 \\
\hline 2. & $\begin{array}{l}\text { Edit photos and videos with the } \\
\text { photo/video editor application on } \\
\text { Smartphone }\end{array}$ & 44 & 51 & 8 & 3 & 1 & 1.75 \\
\hline 3. & $\begin{array}{l}\text { Write articles or posts to Internet } \\
\text { forums (journal/online } \\
\text { news/opinion) on Smartphone }\end{array}$ & 48 & 43 & 7 & 9 & 0 & 1.79 \\
\hline 4. & $\begin{array}{l}\text { Comment on reading on Internet } \\
\text { forums (journal/online } \\
\text { news/opinion) on Smartphone }\end{array}$ & 40 & 54 & 5 & 7 & 1 & 1.83 \\
\hline 5. & $\begin{array}{l}\text { Send files via email/gmail/yahoo on } \\
\text { Smartphone }\end{array}$ & 8 & 24 & 25 & 42 & 8 & 3.17 \\
\hline
\end{tabular}

Ket : TP : Tidak Pernah, J : Jarang, C: Cukup, S : Sering, SS : Sangat Sering

Source: Processed Researcher 2020 
The result of the answer in Table 8 above is that the Group of Digital Immigrants is interested in the production/participation in the first Smartphone to send files via email/yahoo / Gmail with the highest average of 3.17 meaning Of Enough. The second most used production/participation is to take pictures/selfies/videos using a Smartphone of 2.85, which means simple. The third production/participation is to comment on readings on internet forums (journals/opinions/news) online of 1.83, which has the meaning of Rare. Next is the production/participation to write articles/opinions to internet forums (journals/opinions/news online) of 1.79 which means never, while respondents' last production/participation is to edit photos/videos on Smartphones only by 1.75 which means never.

Table 9 is a descriptive analysis of the dimensions of production/participation based on answers from 107 respondents who are lecturers and employees at the University of Muhammadiyah Malang aged 40-60 years are as follows:

Table 9 Descriptive Analysis of online repertoire based on Dimensions of Social Welfare Services

\begin{tabular}{|c|c|c|c|c|c|c|c|}
\hline No. & Statements & $\mathrm{TP}$ & $\mathrm{J}$ & $\mathrm{C}$ & $S$ & SS & Mean \\
\hline 1. & $\begin{array}{l}\text { Find health information or about diseases on } \\
\text { health care applications (healthcare/halo } \\
\text { doc/ google, et al) on Smartphone }\end{array}$ & 7 & 38 & 26 & 33 & 3 & 2.88 \\
\hline 2. & $\begin{array}{l}\text { Consult online with your doctor at } \\
\text { HALODOC or other health applications } \\
\text { using your Smartphone }\end{array}$ & 75 & 21 & 7 & 3 & 1 & 1.45 \\
\hline 3. & $\begin{array}{l}\text { Find tax information through SAMSAT } \\
\text { Online or Google using Smartphone }\end{array}$ & 53 & 41 & 11 & 2 & 0 & 1.64 \\
\hline 4. & $\begin{array}{l}\text { Using the application for life insurance } \\
\text { (Jiwasraya, Reksadana, Sinarmas, or others) } \\
\text { on Smartphone }\end{array}$ & 94 & 8 & 2 & 3 & 0 & 1.20 \\
\hline 5. & $\begin{array}{l}\text { Find information about hospital services or } \\
\text { doctor's schedule in the Smartphone } \\
\text { application }\end{array}$ & 40 & 43 & 16 & 6 & 2 & 1.94 \\
\hline
\end{tabular}

Ket : TP : Tidak Pernah, J : Jarang, C: Cukup, S : Sering, SS : Sangat Sering

Source: Processed Researcher 2020

The result of the answer in Table 9 above is that the Group of Digital Immigrants is interested in social welfare services on smartphones; the first is to search for information about health in Google / Healthcare / Halodoc with the highest average of 2.88 which means ENOUGH. The second most used social welfare service is to find information about hospital services/doctor schedules using Smartphones of 1.94 which means rare. The third social welfare service is to search for tax information on SAMSAT Online / Google of 1.64, which means NEVER. Furthermore, social welfare services to consult with doctors in HALODOC or other apps with a Smartphone of 1.45 which means never, while the last social welfare service used by respondents is to find information about life insurance (Jiwasraya / Reksadana / Sinarmas / other) on Smartphones only 1.20 which means NEVER. 
Next is the discussion about the online repertoire on Smartphones, namely by looking at the greatest value in each dimension. The value will show the online repertoire on Smartphones by immigrant digital groups. Here is the result of the value of each dimension in variable $\mathrm{Y}$ that is the online repertoire on Smartphones:

Table 10 Cross Value Loading Dimension Contribution in Variable Y

\begin{tabular}{llc}
\hline Variable & Dimension & Loading factor \\
\hline \multirow{4}{*}{$\begin{array}{l}\text { Online Repertoire } \\
\text { on Smartphone }\end{array}$} & Entertainment & 0.636 \\
\cline { 2 - 3 } & Transaction & 0.806 \\
\cline { 2 - 3 } & Consumtion & 0.849 \\
\cline { 2 - 3 } & Production/Participation & 0.759 \\
\cline { 2 - 3 } & Social Welfare Services & 0.737 \\
\hline
\end{tabular}

Source: Processed Researcher 2020

From the 5-dimensional analysis based on 25 items in each dimension about the activities carried out by respondents on Smartphones connected with the Internet such as entertainment, transactions, consumption, production/participation and social welfare services, there are 5 dimensions with varied answers have values following the Table above. By distinguishing online activities in Smartphones based on dimensions or themes, the slope of numbers in analytical findings can be seen specifically based on the theme. This is a function because the Internet offers users an almost immeasurable range of options (Olsson et al., 2019b). Individuals have limited time to prioritize selectively using the Internet according to (Hasebrink \& Hepp, 2017), thus creating an individual online repertoire.

The value of each repertoire dimension has a loading factor value above 0.6 which proves that each dimension has a validity value in looking at the contribution to the online repertoire on Smartphones. Of the 5 dimensions, consumption has the highest loading factor value of 0.849 , which indicates that the consumption dimension is the dimension that most contributes to the online repertoire variable. This proves that the online repertoire of Digital Immigrant group is in the consumption dimension. This group uses Smartphones more often for consumption activities such as buying goods through e-commerce, booking transportation tickets or hotels, using Gojek Grab services to buy things. The rapid development of information and communication technology has an impact on changes in public spending and consumption.

Nowadays, people use technology to buy goods and services using e-commerce. This phenomenon is where e-commerce provides shopping options for people without coming directly to the took (BPS, 2019). Consumption using e-commerce is one of the things that makes the community shift to transaction culture. From Social Research \& Monitoring Soclab.com data (in Ridwan et al., 2018) in 2015 Internet users in Indonesia reached 93.4 million, with 77 per cent of them are looking for product information or online shopping. According to KataData in 2016 (in iMarketology, 2020), the number of online consumers in Indonesia has reached 8.7 million people with the number of e-commerce 
transactions reaching 144 trillion rupiahs. Indonesia is one of the countries with a high level of sales through e-commerce. Compared to other countries, Indonesia notes that $41 \%$ of their sales come from Jakarta and ICD research institute predicts that the e-commerce market in the country will grow 42\% from 2012-2015, higher than Malaysia (14\%), Philippines 28\% and Thailand 22\% (Ridwan et al., 2018). Indonesia is one of the fastest-growing e-commerce countries globally with a growth of $78 \%$ in 2018 ; this number is driven by the large number of Internet users in Indonesia which is the strength in driving the growth of e-commerce to reach 100 million users (Widowati, 2019).

Consumption here is related to transactions that are currently very easy for individuals to transact using m-banking / i-banking / digital wallet. Harahap (2018), in his research, revealed that the development of online shopping is also facilitated by services such as banking to pay for the goods he buys. Thus, transactions have the second-highest loading factor value after consumption of 0.806. Transactions here are online activities carried out in transmit using Smartphones, for example, m-banking / digital wallets. Transacting using Smartphones is a digital innovation that makes the banking sector develop businesses to improve their distribution channels (Sihotang \& Sekarsari, 2018). 63.5\% of online transactions are used for online shopping payments out of 88 million Internet users in Indonesia (APJII, 2018). In addition to m-banking / i-banking, startup businesses make businesses develop innovations in digital wallets Gopay, Ovo, Dana (Tazkiyyaturrohmah, 2018). Nowadays, e-money is the public's choice as an intrusion into the payment of the digital economy (Tazkiyyaturrohmah, 2018).

The value of the loading factor contributing to the online repertoire in the next Smartphone is Production/participation with 0759. This dimension is a mode of expression that focuses on genres and topics. In Hasebrink and Hepp (Hasebrink \& Hepp, 2017), online repertoire can be seen in genre and topic elements. In production/participation, genres and topics are focused on taking pictures, editing, reading, commenting on opinions sending important files. Technological advances make it easier for audiences to do fun activities using smartphones, such as taking pictures/ selfies. Selfies are objects of art, and it is a practice that forms a new pattern by posting them on social media (Raditya, 2014). In fact, in a survey by Indonesia Consumer Mobile Habit and Data in 2019, 93\% of respondents out of 1,120 people, used Smartphones to take pictures rather than call (Syarizka, 2019).

The next loading factor value is the dimension of social welfare services with 0.737 . Although the average answer of this dimension tends to say a lot NEVER rather than VERY OFTEN, the loading factor value for this dimension contributes to the online repertoire and is greater in value than the entertainment dimension with the average answer VERY OFTEN than NEVER. The answer's tendency is not as a reference to look at the individual repertoire but rather the value of loading factor or the overall answer of the items in each dimension. Therefore, the entertainment dimension has a loading factor above 0.6 which is 0.636 and is still said to contribute to the online repertoire variable. 
The study (Olsson et al., 2019b) provides the main argument that following the news or using i-banking / m-banking transactions is a repertoire of the elderly group. However, the strong connections between various activities are positively correlated, how the elderly group can combine those 5 dimensions into the activities that are simultaneously used. On the other hand, in this study, it can be seen that almost similar connections and adjacent values of each loading factor between dimensions, namely between consumption dimensions (0.849) have a closeness of value to the dimension of the transaction (0.806). In previous research suggested that consumption using e-commerce is of course very closely related to how individuals transact, and the transactions used in this digitalization era are certainly online transactions using Smartphones with data results from $63.5 \%$ of Indonesians use online transactions to pay for online shopping from 88 million Internet users (APJII, 2018)(Yesicha \& Sulistyani, 2019).

The closest correlation of loading factor value is the dimension of production/participation (0.759) with social welfare services (0.737). Olsson's research, et al. (Olsson et al., 2019b) also provides its arguments regarding the dimensions of production/participation as well as social welfare services that have a lower value, because activities such as writing comments or consulting with insurance agents are very not common compared to activities such as reading news online. This research is also comparable to Olsson's research argument that writing comments or consulting a doctor in Halodoc is a very uncommon activity compared to buying goods online or online transactions.

In contrast to Olsson's research et al. (Olsson et al., 2019b), media as entertainment has a positive correlation with consumption and so is behind it. On the other hand, media use as an entertainment dimension in this study shows a minimal number. However, it is still stated to contribute to the online repertoire on Smartphones with a value of 0.636 above the value to validity (0.6). In contrast to Jung's research et al. (Jung et al., 2014), who argues in his research in South Korea, social media applications have the highest smartphone use aspects. Facebook accounts for $38.6 \%$ of leading apps used from the time users spend playing Smartphones. However, what needs to be underlined is, in Jung, et al (Jung et al., 2014), the criteria of respondents who strongly supported his research were 20 years old $(41.1 \%)$ and 30 years old (32.2\%), 40 years old only $14.4 \%$, and 50 years old only $4.9 \%$. This proves that research on the age of the elderly on social media is deficient in use compared to adolescence. Characteristics of elderly or late adulthood have considerations in using smartphones for activities such as consumption or transactions compared to entertainment. However, in terms of the entertainment dimension on the item "Chatting on Whatsapp" has a respondent's answer that shows often using such activities and is comparable to Jung's research, et al. (Jung et al., 2014) that messaging apps are highly loved in South Korea to be able to make free calls, send images/videos/sounds and make it easy to communicate. Other items in the entertainment dimension do not really show a high number that can show a high interest in entertainment on Smartphones. 
Furthermore, variable $\mathrm{X}$ 's influence is the frequency of smartphone usage with variable Y, which is the online repertoire in Smartphones. The table below is the result to see the calculation of hypothesis that is variable $\mathrm{X}$ that affects significantly to variable $\mathrm{Y}$. Test criteria state that if the path coefficient is a positive value and if the $t$-statistical value of $\geq t$ table (1.96), then it is stated that there is a significant influence of variable $\mathrm{X}$ on variable $\mathrm{Y}$ of hypothesis test result can be known through the following table:

Table 11 Nilai T-Statistik Variabel X

\begin{tabular}{|c|c|c|}
\hline Variable X & Variable $Y$ & T-statistic \\
\hline Frequency of Use & $\begin{array}{l}\text {-Online Repertoar on } \\
\text {-Smartphone }\end{array}$ & 4.526 \\
\hline
\end{tabular}

Source: Processed Researcher 2020

From the results above, it can be seen that the $\mathrm{X}$ variable frequency has a t-statistical value of > t-Table (1.96), which has a significant influence on the variable Y (online repertoire on Smartphones).

The frequency has a significant influence on the online repertoire on Smartphones. The t-statistical value of Frequency $(4,526)>$ of t-Table (1.96) which means that Frequency has a significant influence on the online repertoire on Smartphones. Frequency here is one of The Uses and Gratification theory items that emphasizes the motives and needs felt by the audience. This theory is one of the communication theories that focus on social communication. The basic assumption of this theory is that the audience is considered an active party involved in using the media. This theory considers that the audience is an active agency with good media literacy and understands the expected expectations and satisfaction (Arifin, 2013). In this study, the repertoire results from the number of media used by individuals in various situations, the number of media contacts, and the variety of content used so that it sees the one thing that is most prominently used by the individual.

The Uses and Gratification approach (example, Rosengren et al., 1985) is the most prominent explanation concept for selective media exposure, thus adapting this theory to a repertoire-oriented approach that is very influential in analyzing gratification patterns that is to identify groups of media users based on a combination of motives used to use media (Hasebrink \& Domeyer, 2012). The second possibility in using the Uses and Gratification approach is to open a media-oriented or content-oriented approach used with frequency levels spent, for example, overnight, one week, or even continuously (Hasebrink \& Domeyer, 2012).

The media repertoire study in Hasebrink \& Domeyer's research (Hasebrink \& Domeyer, 2012) argues that frequency and duration are used to view a single media or media used by individuals. However, there must be other efforts to develop a repertoire of Frequency and duration and other aspects that need to be emphasized. However, Frequency is the main element in looking at the media repertoire; with the known Frequency of media use in individuals, it can be clearly seen the time spent using the media. This is following the 
assumption of Uses and Gratification theory that the audience is an active part in choosing the media used based on a certain motive.

Besides, in Jung et al. (Jung et al., 2014), the Uses and Gratification approach is a construction that focuses on the use that people have to use the media about the satisfaction they can achieve. This depends on the assumption that users are no longer passive, but rather active audiences who use content or media to create meaningful experiences (Baran \& Davis, 2011). Theoretically, this idea supports the idea that audiences/individuals seek various forms of satisfaction by selecting an application on a Smartphone, certainly based on the amount of time spent using the content/media to meet its objectives. The decision is a decision based on the individual's desire to use which platform or content he chooses in fulfilling his satisfaction (Jung et al., 2014). The study in Jung's research, et al. (Jung et al., 2014) also placed the habit as a concept construction related to Uses and Gratification, that The Construction of Uses and Gratification approach according to his research that habits can determine the pattern of media consumption in the future so that habits can determine the repertoire of media based on the Frequency of time spent using the media. Although smartphone owners have many applications, the selection of smartphones' applications will form a habit even though the audience/individual has a limited time or other activities outside the use of mobile phones. Audiences won't use all the options available on smartphones, but audiences will evaluate and determine the best app for their needs (Jung et al., 2014). Evaluation of the results of smartphones' applications will form a concentration of the required content based on habitual tendencies carried out.

From Jung's research, et al. (Jung et al., 2014) used the Uses and Gratification approach in South Korea that the online repertoire in Smartphones will be concentrated high on social interactions and relationships. Another empirical study confirmed that U\&G related to communication is the most important function to look at the Frequency used in smartphone use (Jung et al., 2014). The Use and Gratification study by Bødker, et al. (2009) emphasized that smartphone use has the highest satisfaction in communication and social interaction. On the other hand, in this study, Frequency has a high value looking at its influence on smartphones' online repertoire. However, the difference is that the repertoire in Smartphones that contribute more is to the dimension of consumption. In this dimension of consumption, respondents have a higher loading factor value than other dimensions, one of which is the entertainment dimension, whose items ask about communication and interaction. Even so, the entertainment dimension items on "Chatting on Whatsapp" have the highest average of the items on each dimension, indicating that respondents often use WhatsApp as a communication tool. The Uses and Gratification theory shows that communication and interaction seen from Frequency are very significant, and previous research has also stated that (Jung et al., 2014); (Bødker et al., 2009).

\section{CONCLUSION}

Of the 5 dimensions formed on the online repertoire in Smartphones based on the following themes (1) entertainment, (2) transactions, (3) consumption, (4) production/participation, (5) social welfare services, that the online repertoire in Smartphones that have the largest contributed is in the consumption dimension with a 
loading factor value of 0.849 . This means that digital groups of immigrants aged 40-60 years are active consumers who spend much time on Smartphones to shop online using ecommerce applications on Smartphones. Variable X is Frequency Usage with a statistical value of 4,526 > from t-table 1.96 has the dominant influence on the online repertoire on Smartphones. This means that the longer the use of Smartphones, the more online shopping activities by individuals using e-commerce applications on Smartphones.

\section{REFERENCES}

APJII. (2018). Penetrasi dan Perilaku Pengguna Internet Indonesia. Asosiasi Penyelenggara Jasa Internet Indonesia, 1-34.

Arifin, P. (2013). Persaingan Tujuh Portal Berita Online Indonesia berdasarkan Analisis Uses and Gratifications. Jurnal ILMU KOMUNIKASI, 10(2), 195-211. https://doi.org/10.24002/jik.v10i2.353

Arikunto, S. (2002). Prosedur Penelitian Suatu Pendekatan Praktek (Rev.VI). PT Rineka Cipta.

Autry, A. J., \& Berge, Z. (2011). Digital natives and digital immigrants: getting to know each other. Industrial and Commercial Training, 43(7), 460-466. https://doi.org/10.1108/00197851111171890

Azzura, S. N. (2019). Indonesia Jadi Negara Pengguna Internet Terbesar ke-5 di Dunia | merdeka.com.

Baran, S., \& Davis, D. (2011). Mass communication theory: Foundations, ferment, and future (5th ed.). Nelson Education.

Bødker, M., Gimpel, G., \& Hedman, J. (2009). The user experience of smart phones: a consumption values approach. Proceedings the 8th Global Mobility Roundtable: Transformation Through Mobility, GMR, Cairo, Egypt, May.

BPS. (2019). Statistik E-Commerce 2019. In Badan Pusat Statistik. BPS-Statistics Indonesia.

Edgerly, S., Vraga, E. K., Bode, L., Thorson, K., \& Thorson, E. (2018). New media, new relationship to participation? A closer look at youth news repertoires and political participation. Journalism \& Mass Communication Quarterly, 95(1), 192-212. https://doi.org/10.1177/1077699017706928

Ferguson, D. A., \& Perse, E. M. (1993). Media and audience influences on channel repertoire. Journal of Broadcasting \& Electronic Media, 37(1), 31-47. https://doi.org/10.1080/08838159309364202

Friemel, T. N. (2016). The digital divide has grown old: Determinants of a digital divide among seniors. New Media \& Society, 18(2), 313-331. https://doi.org/10.1177/1461444814538648

Geladi, P., \& Kowalski, B. R. (1986). Partial Least-Squares Regression: a Tutorial. Analytica Chimica Acta, 185, 1-17.

Givskov, C., \& Deuze, M. (2018). Researching new media and social diversity in later life. New Media \& Society, 20(1), 399-412. https://doi.org/10.1177/1461444816663949 
Harahap, D. A. (2018). Perilaku Belanja Online di Indonesia: Studi Kasus. JRMSI-Jurnal $\begin{array}{llll}\text { Riset Manajemen } \quad \text { Sains } & \text { Indonesia, 213. }\end{array}$ https://doi.org/10.21009/jrmsi.009.2.02

Hasebrink, U., \& Domeyer, H. (2012). Media repertoires as patterns of behaviour and as meaningful practices: A multimethod approach to media use in converging media environments. Participations, https://doi.org/10.1515/COMMUN.2006.023

Hasebrink, U., \& Hepp, A. (2017). How to research cross-media practices? Investigating media repertoires and media ensembles. Convergence, 23(4), 362-377. https://doi.org/10.1177/1354856517700384

Hasebrink, U., \& Popp, J. (2006). Media repertoires as a result of selective media use. A conceptual approach to the analysis of patterns of exposure. Communications, 31(3), 369-387. https://doi.org/10.1515/COMMUN.2006.023

Heeter, C. (1985). Program selection with abundance of choice: A process model. Human Communication Research, 12(1), 126-152. https://doi.org/10.1111/j.14682958.1985.tb00070.x

iMarketology. (2020). Apa yang Diungkapkan Data Tentang Pasar Online Indonesia dan Global?

Jung, J., Kim, Y., \& Chan-Olmsted, S. (2014). Measuring usage concentration of smartphone applications: Selective repertoire in a marketplace of choices. Mobile Media \& Communication, 2(3), 352-368. https://doi.org/10.1177/2050157914542172

Kim, S. J. (2016). A repertoire approach to cross-platform media use behavior. New Media \& Society, 18(3), 353-372. https://doi.org/10.1177/1461444814543162

Loen, T. (2018). Karakter Pengguna Internet Indonesia di 2017.

Masitha, R. U., Eka Bonita, E. A., \& Bonita, E. A. E. (2019). Pengaruh Digital Campaign Web Series Sore Terhadap Keputusan Pembelian Melalui Brand Awareness Tropicana Slim Stevia di Kalangan Remaja-Dewasa Muda. Jurnal Riset Komunikasi, 2(2), 149156. https://doi.org/10.24329/jurkom.v2i2.61

O’Keefe, G. J., Ward, H. J., \& Shepard, R. (2002). A repertoire approach to environmental information channels. Science Communication, 23(4), 392-409. https://doi.org/10.1177/107554700202300402

Olsson, T., Samuelsson, U., \& Viscovi, D. (2019a). At risk of exclusion? Degrees of ICT access and literacy among senior citizens. Information, Communication \& Society, 22(1), 55-72. https://doi.org/10.1080/1369118X.2017.1355007

Olsson, T., Samuelsson, U., \& Viscovi, D. (2019b). Resources and repertoires: Elderly online practices. European Journal of Communication, 34(1), 38-56. https://doi.org/10.1177/0267323118810852

Raditya, M. H. B. (2014). Selfie dan Media Sosial pada Seni sebagai Wujud Eksistensi. Jurnal Ilmu Sosial Dan Ilmu Politik, 18(1), 26-38. https://doi.org/10.22146/jsp.13096

Ramzan, S., Khan, M. ., \& Khan, I. M. (2010). Dimension reduction and remedy of multicollinearity using latent variable regression methods. World Applied Science 
Journal, 8(4), 404-410. https://doi.org/404-410,2010

Ridwan, H., Masrul, M., \& Juhaepa, J. (2018). Komunikasi Digital pada Perubahan Budaya Masyarakat E-Commerce dalam Pendekatan Jean Baudrillard. Jurnal Riset Komunikasi, 1(1), 99-108. https://doi.org/10.24329/jurkom.v1i1.17

Rosengren, K. E., Wenner, L. A., \& Palmgren, P. (1985). Media gratifications research: Current perspectives. SAGE Publications, Incorporated.

Sihotang, E. T., \& Sekarsari, L. A. (2018). Motivasi Penggunaan Layanan Internet Banking dan Hubungannya dengan Perbedaan Gender. Jurnal Manajemen Dan Kewirausahaan, 6(2), 170-180. https://doi.org/10.26905/jmdk.v6i2.2331

Syarizka, D. (2019). 93\% Orang Indonesia Memakai Smartphone untuk Berfoto Ria, Bukan Menelepon - Teknologi Bisnis.com.

Taneja, H., Webster, J. G., Malthouse, E. C., \& Ksiazek, T. B. (2012). Media consumption across platforms: Identifying user-defined repertoires. New Media \& Society, 14(6), 951-968. https://doi.org/10.1177/1461444811436146

Tazkiyyaturrohmah, R. (2018). Eksistensi Uang Elektronik Sebagai Alat Transaksi Keuangan Modern. Muslim Heritage, 3(1), 23-44. https://doi.org/10.21154/muslimheritage.v3i1.1240

Widowati, H. (2019). Indonesia Jadi Negara dengan Pertumbuhan E-Commerce Tercepat di Dunia | Databoks.

Yesicha, C., \& Sulistyani, A. (2019). Dapur Redaksi Berita Pemerintahan Media Daring Riau. In "Communication and Information Beyond Boundaries" (pp. 37-44). AKSEL MEDIA AKSELERASI.

Ytre-Arne, B. (2019). Media use in changing everyday life: How biographical disruption could destabilize media repertoires and public connection. European Journal of Communication, 34(5), 488-502. https://doi.org/10.1177/0267323119869112

Yuan, E. J., \& Webster, J. G. (2006). Channel repertoires: Using peoplemeter data in Beijing. Journal of Broadcasting \& Electronic Media, 50(3), 524-536. https://doi.org/10.1207/s15506878jobem5003_10 